\title{
Suppression of brainstem reflexes in barbiturate coma
}

\author{
Padraic J Grattan-Smith, Warwick Butt
}

\begin{abstract}
Brainstem reflexes were examined in 23 children treated with thiopentone infusion and correlated with serum thiopentone concentrations. The results suggest that if all brainstem reflexes are lost with a serum thiopentone concentration less than $\mathbf{4 0} \mathrm{mg} / \mathrm{l}$, it is unlikely to be due to the thiopentone alone. Other causes including brain death need to be considered. (Arch Dis Child 1993; 69: 151-152)
\end{abstract}

High dose barbiturate infusion has been increasingly used in patients with status epilepticus or uncontrolled intracranial hypertension. These are a high risk group of patients with a substantial mortality rate. A major disadvantage of this form of treatment is neurological suppression that can be so marked that the patient may lose brainstem reflexes and appear brain dead. The clinician is then placed in the disturbing position of not knowing if this represents a transient drug effect or the fatal progression of the underlying encephalopathy. It is known that the pupillary reaction to light is usually preserved in barbiturate coma, ${ }^{1}$ but a more precise relationship between barbiturate concentrations and brainstem reflexes, particularly in the intensive care setting, has not been established.

\section{Patients and methods}

We examined the brainstem reflexes of 23 children in the intensive care unit of the Royal Children's Hospital, Melbourne between January 1988 and December 1989. The thiopentone was given initially as a slow bolus of $5 \mathrm{mg} /$ $\mathrm{kg}$, repeated up to three times, and followed by a constant infusion at an initial rate of $5 \mathrm{mg} / \mathrm{kg}$ per hour. The dose was adjusted on the basis of clinical response and seizures as detected on a single channel electroencephalogram (EEG) continuously displayed at the bedside. All patients required mechanical ventilation and were examined when haemodynamically stable and normothermic. Blood was taken to measure the thiopentone concentration at the time of examination of brainstem reflexes. This was done on a daily basis while the patient was comatose. The most suppressed brainstem reflexes were correlated with the simultaneous thiopentone concentration. The concentrations of other sedative drugs were also measured. EEGs using long interelectrode distances were performed on the first seven patients seen in the study. Seven patients received dopamine infusions with a maximum dose of $10 \mu \mathrm{g} / \mathrm{kg} / \mathrm{min}$. The patients have been followed up for at least one year and their outcome graded.

\section{Results}

The results are given in the table. Although other brainstem reflexes were frequently lost, the pupillary response to light was absent in only four patients. In two this coincided with the highest thiopentone concentrations recorded: in patient 1 it was $70 \mathrm{ml} \mathrm{g} / 1$ and in patient 2 it was $59 \mathrm{mg} / \mathrm{l}$. The thiopentone concentration of patient 7 was $40 \mathrm{mg} / 1$ but a simultaneous clonazepam concentration was $1946 \mu \mathrm{mol} / \mathrm{l}$ (therapeutic range $<15 \mu \mathrm{mol} / \mathrm{l}$ ). In all three the light reaction returned on the next day. The fourth patient who lost all brainstem reflexes, patient 21 , was brain dead at the time of the examination. The EEGs showed a good correlation with the thiopentone concentrations with electrocerebral silence present in patients 1 , 7 , and 8 (concentrations of 70,40 , and $38 \mathrm{mg} / \mathrm{l}$ ), burst suppression in patient $10(34 \mathrm{mg} / \mathrm{l})$, and diffuse slowing with super added fast activity in patients 12,22 , and $23(29,9$, and $5 \mathrm{mg} / \mathrm{l})$. As this did not seem to be providing additional information formal EEGs were not done on the final 16 patients in the study.

\section{Discussion}

The dilemma over the diagnosis of brain death in patients treated with barbiturate coma would seem to be quite common as most sizable studies report a high mortality and three of our patients died. There is some information from these studies on the effect of barbiturates on brainstem reflexes. Lowenstein et al used pentobarbitone inducing a burst suppression pattern with concentrations ranging from 4 to $21 \mathrm{mg} / \mathrm{l}^{2}$ All brainstem reflexes except the pupillary response to light were lost. Young et al also used pentobarbitone in four adults maintaining concentrations between 20 and $40 \mathrm{mg} / \mathrm{l}$ to produce a burst suppression pattern, again with preservation of the light reflex. ${ }^{3}$ Tasker et al noted that two of their patients lost the pupillary response to light at thiopentone concentrations of 58 and $77 \mathrm{mg} / 1$ respectively. ${ }^{4}$ The first patient recovered but the second died. It was observed with this patient that once the thiopentone had been stopped, a further five days of support were required before all the drug had been eliminated. Osorio and Reed used pentobarbitone to treat 12 adults and found that the pupillary light reflex was not observed when the serum pentobarbitone concentrations approached $50 \mathrm{mg} / 1 .^{5}$ Dopamine infusion has been reported to cause fixed dilated pupils ${ }^{6}$ but the dose was three times greater than the maximum dose used in our study and we feel this is unlikely to have been a contributing factor in our patients.

When faced with a patient who has lost all brainstem reflexes during barbiturate coma, one 
Patient details and results of thiopentone administration

\begin{tabular}{|c|c|c|c|c|c|c|c|c|}
\hline $\begin{array}{l}\text { Patient } \\
\text { No }\end{array}$ & $\begin{array}{l}\text { Age } \\
\text { (months) }\end{array}$ & $\begin{array}{l}\text { Underlying } \\
\text { diagnosis }\end{array}$ & $\begin{array}{l}\text { Pupillary } \\
\text { reaction to } \\
\text { light }\end{array}$ & $\begin{array}{l}\text { Corneal } \\
\text { reaction }\end{array}$ & $\begin{array}{l}\text { Gag } \\
\text { reflex }\end{array}$ & $\begin{array}{l}\text { Oculocephalic } \\
\text { reflex }\end{array}$ & $\begin{array}{l}\text { Thiopentone } \\
(\mathrm{g} / \mathrm{l})\end{array}$ & Outcome \\
\hline 1 & 2 & Meningitis & $\mathbf{A}$ & A & A & A & 70 & 2 \\
\hline 2 & 14 & Head injury & $\mathbf{A}$ & A & A & $\mathbf{A}$ & 59 & 3 \\
\hline 3 & 0 & Birth asphyxia & P† & $\mathrm{A}$ & A & A & 57 & 3 \\
\hline 4 & 82 & Meningitis & $P f$ & A & A & A & 53 & 3 \\
\hline 5 & 2 & Meningitis & $\mathrm{P}+$ & A & A & A & 43 & 3 \\
\hline 6 & 88 & Head injury & $\mathbf{P}$ & A & A & A & 42 & 2 \\
\hline 7 & 2 & Encephalitis & $\mathrm{A}$ & $\mathrm{A}$ & A & A & 40 & 2 \\
\hline 8 & 5 & Encephalitis & $\mathbf{P}$ & A & A & A & 38 & 3 \\
\hline 9 & 151 & Head injury & $\mathbf{P}$ & A & A & $\mathbf{P}$ & 38 & 1 \\
\hline 10 & 14 & Subarachnoid haemorrhage & $\mathbf{P}$ & A & A & $\mathbf{P}$ & 34 & 1 \\
\hline 11 & 65 & Cerebrovascular accident & $\mathbf{P}$ & A & A & $\mathbf{P}$ & 31 & l \\
\hline 12 & 20 & Status epilepticus & $\mathbf{P}$ & $\mathbf{P}$ & $\mathbf{P}$ & $\mathbf{P}$ & 29 & 2 \\
\hline 13 & 14 & Alper's disease & $\mathbf{P}$ & $\mathbf{A}$ & A & A & 25 & 2 \\
\hline 14 & 21 & Status epilepticus & $\mathbf{P}$ & $\mathbf{P}$ & $\mathbf{P}$ & $\mathbf{P}$ & 21 & 1 \\
\hline 15 & 55 & Cardiac arrest & $\mathbf{P}$ & A & $\mathbf{P}$ & $\mathbf{P}$ & 20 & 4 \\
\hline 16 & 65 & Reye's syndrome & $\mathbf{P}$ & $\ddot{P}$ & $\mathbf{P}$ & $\mathbf{P}$ & 20 & 1 \\
\hline 17 & 4 & Air embolus & $\mathbf{P}$ & $\mathbf{P}$ & A & $\mathbf{P}$ & 18 & i \\
\hline 18 & 126 & Head injury & $\mathbf{P}$ & $\mathbf{P}$ & $\mathbf{P}$ & $\mathbf{P}$ & 17 & 2 \\
\hline 19 & 166 & Head injury & $\mathbf{P}$ & $\mathbf{P}$ & $\mathbf{P}$ & $\mathbf{P}$ & 15 & 4 \\
\hline 20 & 78 & Head injury & $\mathbf{P}$ & $\mathbf{P}$ & $\mathbf{P}$ & $\mathbf{P}$ & 15 & 2 \\
\hline 21 & 126 & Head injury & $\mathbf{A}$ & A & A & A & 15 & 4 \\
\hline 22 & 12 & Head injury & $\mathbf{P}$ & & Paralysed & & 9 & 1 \\
\hline 23 & 12 & Meningitis & $\mathbf{P}$ & $\mathbf{P}$ & $\mathbf{P}$ & $\mathbf{P}$ & 5 & 2 \\
\hline
\end{tabular}

The table is ordered from the highest to lowest thiopentone concentrations.

$\star$ Gag reflex or response to suction of the endotracheal tube.

$\mathrm{A}=\mathrm{absent} ; \mathrm{P}=$ present; $\mathrm{P} t=$ reaction to light present but sluggish

$\ddagger$ The outcome scale is $1=$ functionally normal; $2=$ mild handicap, functionally independent; $3=$ severe handicap requiring dependent care; and 4=died in intensive care unit.

approach is to wait for the drug to be fully metabolised before making a decision about brain death. This, however, may take many days and is an undesirable situation. The delay causes unnecessary suffering to the patient's family and may adversely affect the morale of intensive care staff. Optimum conditions for organ transplantation may not be achieved and other children denied the benefit of the limited number of intensive care beds.

Our findings and those of the literature suggest that if all brainstem relexes have been lost with a thiopentone concentration below $\mathbf{4 0}$ $\mathrm{mg} / \mathrm{l}$, the thiopentone alone is unlikely to be responsible. After other causes including intoxication with other drugs and local pathology producing fixed pupils have been excluded, the diagnosis of brain death should be considered. In the appropriate clinical setting, cerebral angiography can be performed without waiting for the drug to be fully metabolised.

1 Wilkinson HA. Diagnosis and therapy of intracranial hypertension. In: Rippe JM, Irwin RS, Alpert JS, Dalen JE, eds. sion. In: Rippe JM, Irwin RS, Alpert JS, Dalen JE, eds.

2 Lowenstein DH, Aminoff MJ, Simon RP. Barbiturate anesthesia in the treatment of status epilepticus: clinical experience wth 14 patients. Neurology 1988; 38: 395-400.

3 Young GB, Blume WT, Bolton CF, et al. Anesthetic barbiturates in refractory status epilepticus. Can $\mathcal{F}$ Neurol Sci 1980; 7: 291-2.

4 Tasker RC, Boyd SG, Harden A, et al. EEG monitoring of prolonged thiopentone administration for intractable seizures and status epilepticus in infants and young children. Neuropediatrics 1989; 20: 147-53.

5 Osorio I, Reed R. Treatment of refractory generalised tonicclonic status epilepticus with pentobarbital anaesthesia after clonic status epilepticus with pentobarbital anaesthe

6 Ong GL, Burning HA. Dilated fixed pupils due to administration of high doses of dopamine hydrochloride. Crit Care Med 1981; 9: 658-9. 